\title{
Corrigendum: Identification of Cleavage Sites Recognized by the 3C-Like Cysteine Protease within the Two Polyproteins of Strawberry Mottle Virus
}

\author{
Krin S. Mann, Melanie C. Walker and Hélène Sanfaçon * \\ Agriculture and Agri-Food Canada, Summerland Research and Development Centre, Summerland, BC, Canada
}

Keywords: proteolytic processing, viral proteases, plant virus, cleavage site specificity, $3 \mathrm{C}$ protease, picornavirales, secoviridae, in vitro translation

\section{OPEN ACCESS}

Edited and reviewed by: Nobuhiro Suzuki,

Okayama University, Japan

*Correspondence:

Hélène Sanfaçon

helene.sanfacon@agr.gc.ca

Specialty section:

This article was submitted to

Virology,

a section of the journal

Frontiers in Microbiology

Received: 21 August 2017 Accepted: 30 August 2017 Published: 12 September 2017

Citation:

Mann KS, Walker MC and Sanfaçon H

(2017) Corrigendum: Identification of

Cleavage Sites Recognized by the 3C-Like Cysteine Protease within the Two Polyproteins of Strawberry Mottle

Virus. Front. Microbiol. 8:1762. doi: 10.3389/fmicb.2017.01762

\section{A corrigendum on}

Identification of Cleavage Sites Recognized by the 3C-Like Cysteine Protease within the Two Polyproteins of Strawberry Mottle Virus

by Mann, K. S., Walker, M. C., and Sanfaçon, H. (2017). Front. Microbiol. 8:745. doi: $10.3389 /$ fmicb.2017.00745

In the original article, there were mistakes in Table 2 as published. Several listed cleavage sites were derived from virus isolates that did not correspond to the accession numbers provided in the Materials and Methods Section. In addition, the sequence listed for the DMaV NTB-VPg cleavage site was incorrect and showed the sequence for the VPg-Pro cleavage site instead. Corrections to the SMoV MP-CP cleavage site, BRNV MP-CP cleavage site, and DMaV X1-X2, NTB-VPg, and ProPol cleavage sites have been made. Please note that this correction does not change amino acids at conserved positions (highlighted in red or green in the Table). The corrected Table 2 appears below. The authors apologize for this error and state that this does not change the scientific conclusions of the article in any way.

Conflict of Interest Statement: The authors declare that the research was conducted in the absence of any commercial or financial relationships that could be construed as a potential conflict of interest.

Copyright $\odot 2017$ Mann, Walker and Sanfaçon. This is an open-access article distributed under the terms of the Creative Commons Attribution License (CC BY). The use, distribution or reproduction in other forums is permitted, provided the original author(s) or licensor are credited and that the original publication in this journal is cited, in accordance with accepted academic practice. No use, distribution or reproduction is permitted which does not comply with these terms. 
TABLE 2 | Alignment of potential cleavage sites for members of the family Secoviridae.

\begin{tabular}{lllll}
\hline & SMoV & BRNV & CLVA & DMaV \\
\hline P1 SITES & & & & \\
X1-X2 & AQCVEQ/GG & IGLEQE/GF & EHETCQ/GL & TEEELQ/GL \\
X2-NTB & CPAYEQ/SS & DVPLSE/GA & ADVAAQ/SG & EPMMLQ/AG \\
NTB-VPg & EVATEQ/GG & LAFTSE/GG & SSSLAQ/GT & TESELQ/GV \\
VPg-Pro & VRAYEQ/GA & IKPYSQ/GG & RAFSAQ/GE & RGFQLQ/GG \\
Pro-Pol & EVAVQQ/GM & GKFYQQ/GD & PVIVAQ/GP & PADELQ/SE \\
P2 SITES & & & & \\
MP-CP & TRAYEE/GF & DDFVEE/GG & GDAAAQ/GD & LNDSLE/GD \\
\hline
\end{tabular}

Amino acids highlighted in red represents highly conserved positions. Amino acids highlighted in green represent alternative amino acids found at the $-4,-2,-1$, or +1 positions. SMoV, Strawberry mottle virus; BRNV, black raspberry necrosis virus; CLVA, chocolate lily virus A; DMaV, dioscorea mosaic-associated virus; NTB, nucleoside triphosphate binding protein; VPg, viral genome-linked protein; Pro, protease; Pol, polymerase; X1 and X2, unknown; MP, movement protein; $C P$, capsid protein. 